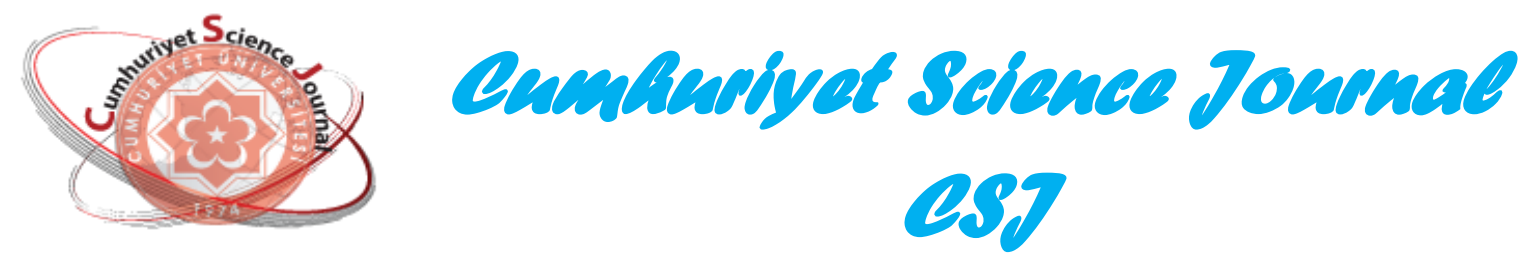

\title{
Determination of the Effects of Speed Bumps on Driver Speeds Via Mobile Cameras and A Survey Application
}

\author{
Arzu ILGAZ ${ }^{1 *}$, Mehmet SALTAN ${ }^{2}$

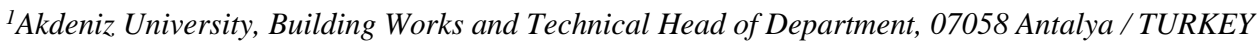 \\ ${ }^{2}$ Suleyman Demirel University, Engineering and Architectural Faculty, Civil Engineering Department, 32260 Isparta /
} TURKEY

Received: 28.09.2017; Accepted: 13.10.2017

http://dx.doi.org/10.17776/csj.340256

\begin{abstract}
Speed bumps are the most frequently used in Turkey as precautions for traffic calming at pedestrian and bicycle intensive sections. In this article, exemplary traffic calming measures applied on the university campus road network for increasing the quality of life of students and personnel along with their results have been put forth. The effects of speed bump applications on driver speeds are evaluated by way of a mobile average speed enforcement system set up on a section inside the Akdeniz University campus with a speed limit of $50 \mathrm{~km} / \mathrm{h}$. The average speeds recorded at the current section with the speed bump in place were compared with the average speeds recorded when there was no speed bump. This article also puts forth a study in which driver opinions on speed bumps determined to be effective in decreasing the speeding behavior of drivers have been examined. Even though the driver speeds decreased, survey results put forth that $50 \%$ of the drivers think that the frequency of speed bumps in the campus is very high. It is emphasized in this study that drivers should comply with the legal speed limits in order to be able to develop a balanced approach with regard to the distribution between all transportation types (pedestrian, bicycle, public transportation, automobile) for campus road network use and to be able to decrease rates of accidents.
\end{abstract}

Keywords: Speed bumps, average speed enforcement, Independent Sample t test, chi-square test.

\section{Kasislerin Sürücü Hızları Üzerindeki Etkisinin Mobil Hız Kameraları ile Tesbiti ve Bir Anket Uygulaması}

\begin{abstract}
Özet: Kasisler Türkiye'de özellikle yoğun yaya ve bisikletlilerin bulunduğu güzergâhlarda trafiği sakinleştirmeye yönelik en fazla kullanılan önlemlerdir. Bu makalede bir üniversite kampüsü içindeki yol ağında, öğrenci ve personellerin yaşam kalitesini artırmak amacıyla yapılan trafiği sakinleştirme çalışmalarının örnek uygulamaları ve sonuçları anlatılmaktadır. Akdeniz Üniversite kampüsü sınırları içinde $50 \mathrm{~km} / \mathrm{s} \mathrm{h}$ 'z limitine sahip bir güzergâha kurulan mobil ortalama hız sistemi yardımı ile kasis uygulamalarının sürücü hızlarına etkisi değerlendirilmektedir. Mevcut güzergâhta kasis varken kaydedilen sürücü ortalama hızları, kasis yokken kaydedilen ortalama hızlarla kıyaslanmıştır. Bu makalede, sürücülerin hız davranışlarını azaltması yönünde etkili olduğu tespit edilen kasisler hakkındaki sürücü görüşlerinin de araştırıldığ bir çalışma sunulmaktadır. Her ne kadar sürücü hızları düşmüş olsa da, anket sonuçlarına göre sürücülerin \%50'si kampüs içerisindeki kasis sıklığının fazla olduğunu düşünmektedir. Bu çalışmada, kampüs yol ağı kullanımında tüm ulaşım türleri (yaya, bisiklet, toplu taşım, otomobil) arasındaki dağılımında dengeli bir yaklaşımın geliştirilmesi ve kaza oranlarının düşmesi için sürücülerin yasal hız limitlerine uyması gerektiğini vurgulanmaktadır.
\end{abstract}

Anahtar Kelimeler: Hız kasisleri, ortalama hız uygulaması, Independent Sample t test, ki-kare testi. 


\section{INTRODUCTION}

Different speed enforcement systems are applied in all countries for solving the speeding problem in traffic. Speed bumps, which are placed horizontally on the sections, are among these enforcement systems. Speed bump applications are among the precautions that are most frequently used at especially children parks, schools, university campuses, sports and residential areas with high pedestrian activity which are suited to speeding due to the road structure and low traffic density in Turkey [1]. The most important advantages of this precaution are that; it is inexpensive, it is very effective in slowing down traffic and that it is suited for bicycle use if designed properly. For example; speed bumps may damage certain parts of vehicles or cause unnecessary fuel consumption as well as noise and environmental pollution since the vehicles have to accelerate in order to gain the speed they lost. In addition, they are questionable aesthetically and because they slow down emergency vehicles as well $[1,2]$.

The objective of traffic calming measures at areas such as university campuses is in general to make traffic as well as the interaction between the $\mathrm{road} / \mathrm{vehicle/bicycle/pedestrian} \mathrm{traffic} \mathrm{safer} \mathrm{by} \mathrm{way}$ of adjusting vehicle speeds. This article determines and evaluates driver speed behaviors at a 50 $\mathrm{km} /$ hour speed limit section inside the Akdeniz University campus with and without speed bumps. The drivers were notified that their average speeds were going to be measured by way of cameras during which license recognition average speed cameras were used to calculate the average speed values based on the times that the vehicles pass in front of the cameras as well as the known distances between the cameras. In this study, the license plate recognition cameras were not placed on a fixed structure but on mobile vehicles. This study focuses on the examination of the speeding behaviors of drivers via mobile average speed enforcement system with/without speed bumps on a campus section where accident rates are high. The difference of this study with other studies carried out in Turkey; (1) license plate recognition cameras have been installed not on a fixed structure but on mobile vehicles and (2) since speed is measured over a longer distance on the section where the cameras have been placed, it has been defined to be more fair in comparison with spot speed application and indicates that speeding behavior is voluntary and not due to an instantaneous loss of concentration. It was determined as a result of the application that speed bumps are effective for decreasing the speeding behavior of drivers. Speeds of speeding vehicles also decreased. Afterwards, surveys were carried out on 729 drivers who regularly enter the campus regarding their opinions on driver properties, speed bump application measure and speed limit applications" and results were evaluated via statistical analyses.

\section{BACKGROUND}

It has been proven in high income countries that traffic calming measures which decrease vehicle speeds at regions with intensive pedestrian and bicycle traffic are effective in decreasing the number of traffic accidents [3,4]. Speed bumps were placed at 16 locations in 5 residential areas at Washington Bellevue in 2001. The 85 percentile speeds which were $58 \sim 63 \mathrm{~km} / \mathrm{hour}$ prior to the placement of the speed bumps decreased down to 39 43 km/hour afterwards. Many residents indicated that speed bumps were effective in decreasing the speeds of vehicles and that they are of the opinion that this measure should be used [5]. It was observed in another study carried out in Holland according to data acquired from fifteen regions where a $30 \mathrm{~km} / \mathrm{h}$ speed limit application was implemented that vehicle speeds were below $30 \mathrm{~km} / \mathrm{hr}$ for $85 \%$ of the vehicles as a result of traffic calming measures resulted and that speed bumps were the most important factor for this [6].

Definition of speeds that provide precise measurements are required when expressway transportation is considered from the perspective of studies on speed. Typically two types of speed data are collected: 'spot speed' and 'average speed'. The spot speed of a vehicle is the independent speed of that vehicle while passing from a certain spot on the road. Whereas average speed is the corridor speed between two different spots [7]. 
Two or more camareas are palced at many locations on a section in average speed application. The license plate and/or vehicle registration data are recorded for the vehicles that enter the system from the first camera location which are then combined with the additional images obtained from the subsequent camera locations in the system which are then matched with the first data. Afterwards, Automatic Name Plate Recognition (ANPR) and Optical Character Recognition (OCR) technologies are used to match the vehicle registration data [8-19]. If the average vehicle speed determined exceeds the legal speed limit, images and violation data (e.g. time, date, speed etc.) are transferred over to a central processing unit from the local processor $[9,13,17,18]$. This technology enables the application of uninterrupted speed application with automation along an extended section. Even though spot speed cameras are effective at locations with a known accident history, average speed cameras have a much greater effect on the drivers since they are applied over a much longer section. The cameras measure the average speeds of vehicles along a significant distance instead of controlling their speeds at a certain spot. Thus, average speed application targets a sustained speeding behavior and may be more acceptable for the public in comparison with single camera applications $[9,11,12,16,17,19$ 25].

If the average vehicle speed determined by average speed enforcement systems exceeds the legally allowed speed limit for that section, images and violation data (e.g.: time, date, speed etc.) are transferred to a central processing unit from the local processor via a communication network. Afterwards, a violation notice is prepared for the verified violations whereas data for vehicles with no violation are deleted in a certain period of time $[9,13,17,18]$. The most important obstacle in the average application for decreasing the speed limits during the first years and expanding the $20 \mathrm{mil} / \mathrm{h}$ network was that the standard cameras did not have type approval for enforcing speed limits under 30 $\mathrm{mil} / \mathrm{h}$. Hence, speed bumps and sharp turns were used. However, even though such speed reduction methods were effective, they were not approved by the users; they increased emissions slightly and posed an obstacle for service and emergency vehicles. Recently, there has been a change for the testing of this system on low speed urban sections (e.g.; $20 \mathrm{mil} / \mathrm{h}$ sections). It has been put forth that technology provides an effective alternative to speed reducing tools (e.g.; bumps) which are relatively expensive, may increase emissions and may pose unnecessary obstacles to emergency vehicles [16, 26, 27]. A survey carried out on British drivers has put forth that $72 \%$ of the participants may support the implementation of the average speed application at $20 \mathrm{mil} / \mathrm{h}$ residential area roads. The ratio of drivers who support speed bumps as an alternative to the average speed enforcement system was $43 \%$ [27].

As has been stated above, this system has 2 functions; the first is to calculate the speeds of the vehicles, whereas the $2^{\text {nd }}$ is to notify of violations and enforce penal sanctions. In this study, only the $1^{\text {st }}$ function of the average speed enforcement systems; that is "speed measurement technique" is used. As put forth in the previous paragraph; even though issues regarding alternatives to speed bumps or other speed control systems are important, they are issues that are outside the scope of the objectives of this article. In this study, the speed behaviors with and without speed bumps of vehicles which use the current section were measured via average speed method after which they were analyzed in addition to the evaluation of survey studies.

\section{MATERIAL AND METHOD}

\subsection{Section Selection and Characteristics}

Average speed enforcement systems can be used on almost all public roads from an urban street with a speed limit of $20 \mathrm{mil} / \mathrm{h}$ to high speed, multi-lane expressways [12]. The section determined in this article was the D section in the Akdeniz University campus. This is a section that is frequently used by pedestrians, bicycle riders as well as vehicles. Overspeeding vehicles attract attention despite the traffic sign (Figure 1) indicating the $50 \mathrm{~km} / \mathrm{h}$ speed limits. The $\mathrm{D}$ section on which mobile average 
speed enforcement system is applied and its physical characteristics have been given in Table 1 .

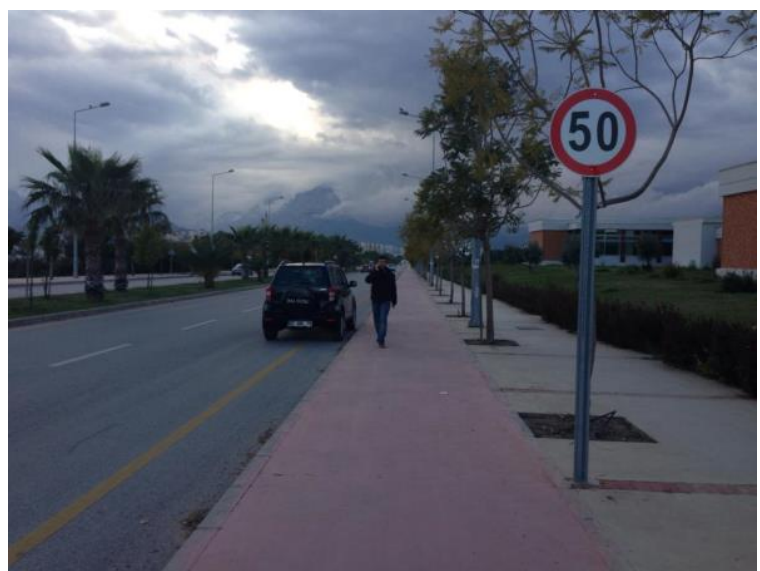

Figure 1. Traffic sign indicating the speed limit for the D section.

Table 1. Physical characteristics of section D.

\begin{tabular}{|c|c|c|c|c|c|c|c|c|}
\hline \multirow[t]{2}{*}{ Section } & \multirow{2}{*}{$\begin{array}{l}\text { Length } \\
\text { (m) }\end{array}$} & \multirow{2}{*}{$\begin{array}{l}\text { Speed Limit } \\
(\mathrm{km} / \mathrm{h})\end{array}$} & Number of lanes & \multicolumn{2}{|c|}{ Lane width (m) } & \multirow{2}{*}{$\begin{array}{c}\text { Number of } \\
\text { intersections }\end{array}$} & \multirow{2}{*}{$\begin{array}{l}\text { Number of } \\
\text { horizontal } \\
\text { curbs }\end{array}$} & \multirow{2}{*}{$\begin{array}{c}\text { Number } \\
\text { of speed } \\
\text { bumps }\end{array}$} \\
\hline & & & $1^{\text {st }}$ spot $2^{\text {nd }}$ spot & $1^{\text {st }}$ spot & $2^{\text {nd }}$ spot & & & \\
\hline $\mathrm{D}$ & 890 & 50 & 2 & 3.50 & 3.50 & 2 & - & 1 \\
\hline
\end{tabular}

In addition, according to studies carried out at the University Security Department, the number of 'recorded' accidents is around 10 per year. The highest number of accidents have occurred on section $\mathrm{D}$ at the University. Figure 2 shows an accident due to speeding on section D. The high number of accidents that takes place annually in an education campus leads us to consider whether the current speed bumps on the campus sections are effective or not. Indeed, increasing the number of speed bumps is not the best solution.



Figure 2. An example for accidents in the campus due to speeding.
There is 1 speed bump on the 890 meter long section where measurements have been carried out for this study. The speed bump has a length of about 3.40 meters and a height of about 4 centimeters with a circular cross-section (Figures 3 and 4).

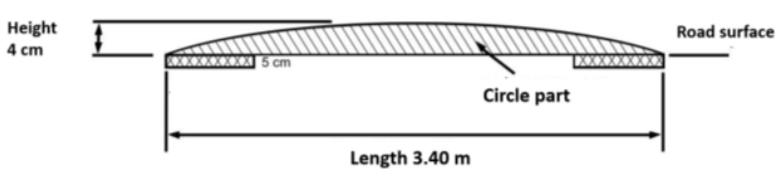

Figure 3. Speed bump cross-section.

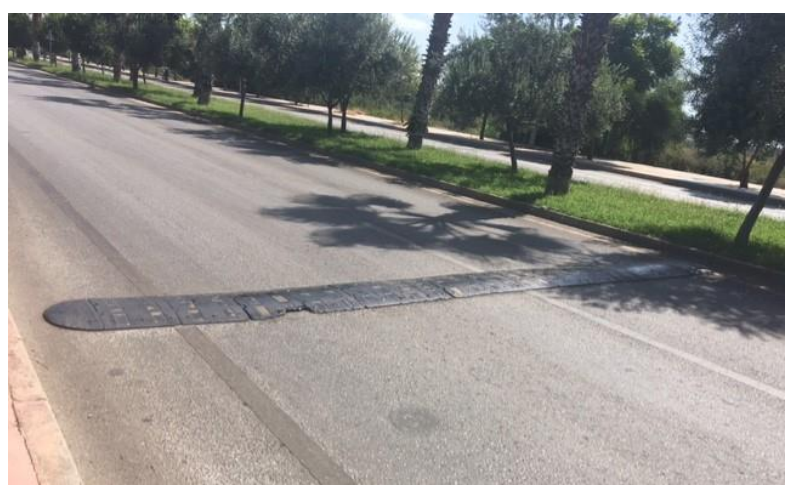

Figure 4. Speed bump appearance. 


\subsection{Speed Measurement System and Data Acquisition}

"Mobile average speed cameras" have been preferred in this study for measuring vehicle speeds. This technology has two basic forms as "carrying a camera from one fixed spot to another and installing the camera on a vehicle". The underlying concept behind this form is to examine the driver speeding behavior changes along the diameter of a corridor. Cameras have been placed inside a blue colored camera mount that is installed on a vehicle in order to protect the camera from weather conditions and vandalism (Figure 5). Two lane license recognition cameras that scan a wider angle have also been placed. License plate recognition cameras are digital cameras with a resolution of $5 \mathrm{MegaPixel} / 75 \mathrm{fps}$ and IP feature.

\subsection{Speed Measurement System and Data Acquisition}

"Mobile average speed cameras" have been preferred in this study for measuring vehicle speeds. This technology has two basic forms as "carrying a camera from one fixed spot to another and installing the camera on a vehicle". The underlying concept behind this form is to examine the driver speeding behavior changes along the diameter of a corridor. Cameras have been placed inside a blue colored camera mount that is installed on a vehicle in order to protect the camera from weather conditions and vandalism (Figure 5). Two lane license recognition cameras that scan a wider angle have also been placed. License plate recognition cameras are digital cameras with a resolution of $5 \mathrm{MegaPixel} / 75 \mathrm{fps}$ and IP feature.

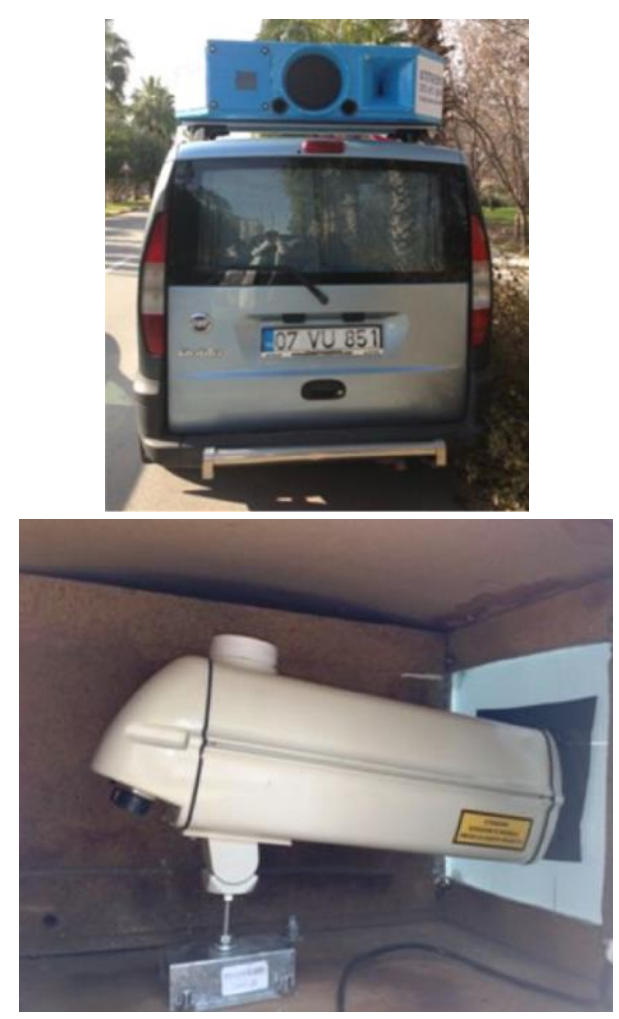

Figure 5. Average speed camera installed on the vehicle.

Each mobile average speed enforcement system was parked on the entrance and exit points along the $\mathrm{D}$ corridor determined by way of geo-coding using a GPS device (Figure 6). The cameras carried out license plate recognition and average speed determination on parked vehicles during the week days of April and May between the hours of 08:0018:00. 


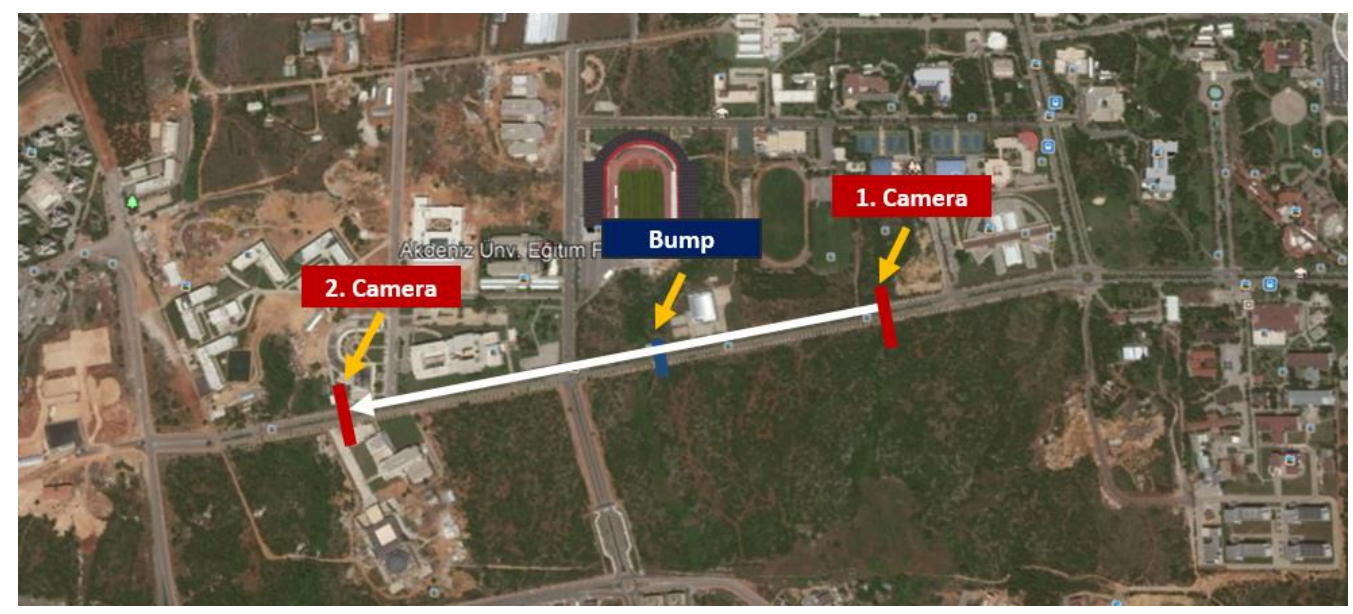

Figure 6. D section inside the campus.

Measurements were carried out on the $50 \mathrm{~km} / \mathrm{h}$ speed limit D-section first with speed bumps for 5 days after which the speed bumps were removed temporarily and measurements were carried out without the speed bump for 3 days (the university administration allowed the removal of the speed bumps for only 3 days). The license plates of the vehicles were scanned via cameras and their average speed values were calculated.

\subsection{Survey Applications}

A survey study was carried out on drivers whose average speeds have been determined regarding whether speed bump applications are acceptable or not. The surveys were distributed to all drivers entering the campus. Of the distributed surveys, 729 were considered to be valid.

\subsection{Method}

The license plates of the vehicles passing by the $1^{\text {st }}$ and $2^{\text {nd }}$ license recognition spots, average speed, speed limit, whether they exceed the average speed limit or not, data and hour information can be seen and saved in Excel format using the software in the central server at the end of all periods. All data saved in Excel format were uploaded to the SAS (Statistical Analysis Software) and were subject to various statistical analyses in line with the goals of the study. The level of significance was determined as 0.05 for this study. First, Independent Sample t test was used for determining the average speed differences between sections with and without speed bump. Data acquired from the survey were uploaded to SPSS (Statistical Package for the Social Sciences) package software after which chisquare test was carried out for analyzing the relationship between the variables and the statistical significance of the chi-square value was examined. These variables were comprised of; "being involved in an accident, opinions on speed limit, tendency to overtake vehicles" $\rightarrow$ "opinions on frequency of speed bumps".

\section{STUDY RESULTS}

\subsection{Average Speed Results}

The before and after states should be compared in order to determine the effects of a traffic enforcement measure [28]. In this study, the compliance of drivers with the speed limits along section D with and without speed bumps have been evaluated for the weekdays during April - May 2013 on the basis of the "average travel speeds" of all vehicles passing from the study sections. First, the average speeds of drivers were evaluated with speed bumps in place on the current section, after which the average speeds were evaluated without the speed bump. Afterwards, the average speeds recorded with the speed bump were compared with those that were recorded without the speed bump. Table 2 shows the results for the mobile average speed system set up on section D with and without speed bump. The number of vehicles monitored with the speed bump was 1057, whereas the 
number of vehicles monitored without the speed bump was 1538. It can be observed that drivers comply with the speed limit along section D when there is a speed bump and their speed average was determined as $49.30 \mathrm{~km} / \mathrm{h}$. The average speed value of the drivers increased to $52.99 \mathrm{~km} / \mathrm{h}$ following the removal of the speed bump. Whereas the average speed of the drivers who violated the speed limit with the speed bump was $57.83 \mathrm{~km} / \mathrm{h}$, this value increased up to $62.54 \mathrm{~km} / \mathrm{h}$ when the speed bump was removed.

Table 2. Findings of the mobile average speed system with and without the speed bump

\begin{tabular}{ccccccc}
\hline Section & $\begin{array}{c}\text { Speed limit } \\
(\mathbf{k m} / \mathbf{h})\end{array}$ & $\begin{array}{c}\text { Section } \\
\text { length } \mathbf{( m )}\end{array}$ & $\begin{array}{c}\text { Number of } \\
\text { vehicles }\end{array}$ & $\begin{array}{c}\text { Vehicle } \\
\mathbf{\%}\end{array}$ & $\begin{array}{c}\text { Average speed } \\
(\mathbf{k m} / \mathbf{h})\end{array}$ & $\begin{array}{c}\text { Speed violation } \\
(\mathbf{k m} / \mathbf{h})\end{array}$ \\
\hline $\begin{array}{c}\text { D2 } \\
\text { D2(without speed }\end{array}$ & $\mathbf{5 0}$ & 890 & 1057 & 40.73 & 49.30 & 57.83 \\
$\begin{array}{c}\text { bump) } \\
\text { Total }\end{array}$ & $\mathbf{5 0}$ & 890 & 1538 & 59.27 & 52.99 & 62.54 \\
\hline
\end{tabular}

4.1.1. The Effects of Speed Bump Use on Average Speed for the D2 Section

Measurements were made with speed bumps on section D2 with a speed limit of $50 \mathrm{~km} / \mathrm{h}$ for 5 days after which the speed bumps were temporarily removed and measurements were made for 3 days without the speed bumps. Independent Samples $t$ test was then carried out in order to examine whether speed bumps are effective on the speed averages of drivers or not (Table 3). Speed average on the section with the speed bumps was 49.31 $\mathrm{km} / \mathrm{h}$ which is below the speed limit, whereas the speed average on the section without the speed bumps was $52.99 \mathrm{~km} / \mathrm{h}$ which is above the speed limit. An increase of $3.68 \mathrm{~km} / \mathrm{h}$ has been observed in the speed averages for the section without the speed bumps. The $\mathrm{p}$ value was $<.0001$ indicating that there was a statistically significant difference between the averages of the speed averages of drivers since the $p$ value was below the significance level of 0.05 . This indicates that speed bumps on this section has a positive effect on the decrease of average speed. When standard deviations were compared; an increase has been observed in the section without the speed bumps (12.9734) in comparison with the section with the speed bumps (9.8241). The greater difference between the speed variance on these sections with the removal of the speed bumps (standard deviation is the square root of the variance) means that speed variance between the vehicles has increased.

Table 3. Independent Samples t test findings for the D2 section with and without the speed bumps

\begin{tabular}{cccccc}
\hline Measurement & $\begin{array}{c}\text { Number of } \\
\text { vehicles }\end{array}$ & $\begin{array}{c}\text { Average } \\
\text { speed }(\mathbf{k m} / \mathbf{h})\end{array}$ & $\begin{array}{c}\text { Standard } \\
\text { Deviation }\end{array}$ & $\mathbf{t}$ & $\mathbf{p}$ \\
\hline With the speed bumps & 1057 & 49.31 & 9.8241 & -7.82 & $<.0001$ \\
Without the speed bumps & 1538 & 52.99 & 12.9763 & \\
\hline
\end{tabular}

\subsection{Survey Findings}

\subsubsection{Characteristics of the Drivers Who Participated in the Survey}

Table 4 shows the "descriptive characteristics" of the drivers according to 729 surveys with $67.7 \%$ male and $32.3 \%$ female drivers. It was observed that $28 \%$ of the drivers were between the ages of $21-30,32 \%$ were between the ages of $31-40$, and $26.9 \%$ were between the ages of 41-50. When the education levels were examined, it was determined that $23.6 \%$ of the drivers were at primary school and high school level, $12.4 \%$ were at college level, $26.6 \%$ were at the undergraduate degree level and that $37.3 \%$ were at graduate degree level. Of the drivers, $40.7 \%$ were comprised of academic, $22.2 \%$ of administrative staff and $14.4 \%$ of students. 
Table 4. Distribution of the descriptive characteristics of the drivers who participated in the survey.

\begin{tabular}{lcc}
\hline Descriptive characteristics & $\mathbf{N}$ & $\mathbf{\%}$ \\
\hline Gender & & \\
\hline Male & 493 & 67.7 \\
Female & 235 & 32.3 \\
\hline Age & & \\
\hline 20 and below & 11 & 1.5 \\
$21-30$ & 204 & 28.0 \\
$31-40$ & 239 & 32.8 \\
$41-50$ & 196 & 26.9 \\
$51-60$ & 62 & 8.5 \\
61 and above & 17 & 2.3 \\
\hline Graduation & & \\
\hline Primary school & 29 & 4.0 \\
High school & 143 & 19.6 \\
College & 90 & 12.4 \\
Undergraduate & 194 & 26.6 \\
Graduate & 103 & 14.1 \\
Doctorate & 169 & 23.2 \\
\hline Job Status at the University & & \\
\hline Academic & 288 & 40.7 \\
Administrative & 157 & 22.2 \\
Student & 103 & 14.5 \\
Other & 160 & 22.6 \\
\hline & & \\
\hline
\end{tabular}

Table 5 shows the drivers' "attitudes towards traffic applications and measures". Of the drivers, $50 \%$ stated that the frequency of speed bumps in the campus is high, $45 \%$ stated that it is sufficient, whereas $4.4 \%$ stated that it is low. When the opinions of the drivers on the speed limits enforced in the campus were asked, $1.6 \%$ stated that the speed limits are high, $52 \%$ stated that the speed limits are low, whereas $42.6 \%$ stated that the speed limits are sufficient.

Table 5. Attitudes on traffic measures of drivers who participated in the survey.

\begin{tabular}{lcc}
\hline $\begin{array}{l}\text { Attitudes of drivers on traffic } \\
\text { applications and measures }\end{array}$ & N & $\%$ \\
\hline Frequency of Speed Bumps & & \\
\hline Low & 32 & 4.4 \\
Sufficient & 327 & 45.0 \\
High & 368 & 50.6 \\
\hline Speed Limits & & \\
\hline High & 11 & 1.6 \\
Low & 362 & 52.8 \\
Sufficient & 292 & 42.6 \\
No Opinion & 20 & 2.9 \\
\hline
\end{tabular}

The behaviors of drivers put forth regarding their own "driving safety and speeding behavior" have been given in Table 6. The question of, "Do you have a tendency to overtake vehicles whenever you have the chance?" was answered as yes by $16.9 \%$, as no by $42.7 \%$ and as maybe by $40.4 \%$. So it is thought that speeding behavior is considered as an acceptable behavior by majority of the drivers. Of the drivers, 38.6\% have not been involved in any accident, $34.2 \%$ have been involved in 1 accident, whereas $16.5 \%$ have been involved in 2 accidents.

Table 6. Driving safety/speeding behavior of drivers who participated in the survey.

\begin{tabular}{lcc}
\hline $\begin{array}{l}\text { Opinions of drivers on their own } \\
\text { driving safety and speeding } \\
\text { behavior }\end{array}$ & $\mathbf{N}$ & $\boldsymbol{\%}$ \\
\hline \multicolumn{1}{l}{ Tendency to Overtake Vehicles } & & \\
\hline Yes & 123 & 16.9 \\
No & 311 & 42.7 \\
Sometimes & 294 & 40.4 \\
\hline Number of Accidents Involved as the Driver & \\
\hline 0 accidents & 231 & 38.6 \\
1 accident & 205 & 34.2 \\
2 accidents & 99 & 16.5 \\
3 accidents & 41 & 6.8 \\
4 accidents and above & 23 & 3.8 \\
\hline
\end{tabular}

\subsubsection{Analysis of the Characteristics of Drivers Who Participated in the Survey}

In this section, chi-square test was used for analyzing the relationship between 2 variables for 729 drivers who participated in the survey and the statistical significance of the chi-square value was examined.

The values related with the 2 variables of "opinions on the frequency of speed bumps" and "number of accidents involved in as the driver" can be seen in Table 7. According to the ratios specified in the table, $41.7 \%$ of those who have been involved in an accident and $58.3 \%$ of those who have not been involved in any accident think that the number of speed bumps is low. The statistical significance of the chi-square value (4.070) was 0.131 which is above the significance level (0.05). This indicates that no statistically significant ddifference has been determined between the drivers who have and have not been involved in accidents according to their opinions on the frequency of speed bumps. 
Table 7. "speed bump"-“accident" chi-square test.

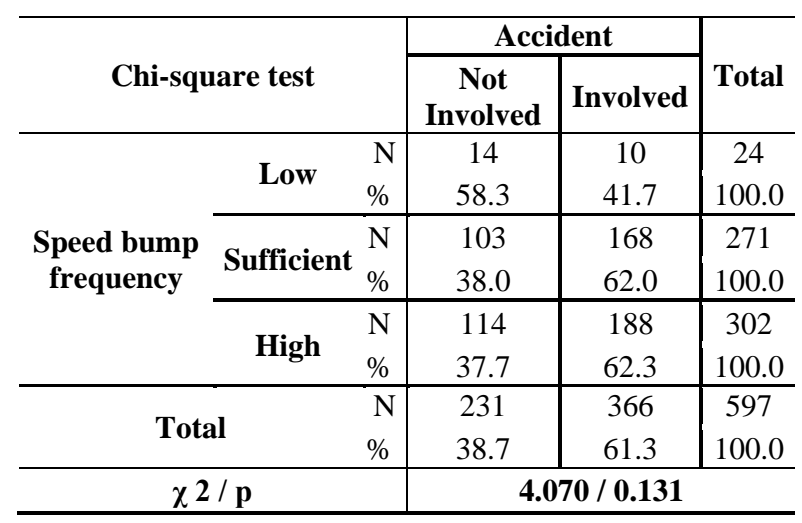

Table 8 shows the values related with the 2 variables of "opinions on the applied speed limit" and "opinions on speed bump frequency". Of those who think that the frequency of speed bumps is sufficient, $81.8 \%$ are of the opinion that the speed limit is high, whereas of those who think that the frequency of speed bumps is high, $62.2 \%$ are of the opinion that the speed limit is low. The statistical significance of the chi-square value (46.557) is 0.000 which is below the level of significance (0.05). This indicates that the difference between the opinions on speed bump frequency according to opinions on speed limit application is statistically significant.

Table 8 shows the values related with the 2 variables of "tendency to overtake vehicles" and "opinions on speed bump frequency". Of those who have a tendency to overtake vehicles, $64.8 \%$ are of the opinion that the speed bump frequency is high, whereas of those who do not have a tendency to overtake vehicles, $48.4 \%$ are of the opinion that speed bump frequency is sufficient. The statistical significance of the chi-square value (15.183) is 0.004 which is below the level of significance (0.05). In other words, it has been determined that the difference between opinions on speed bump frequency according to the tendency to overtake vehicles is statistically significant.

Table 8. "Speed limit, tendency to overtake vehicle" and "speed bump" chi-square test

\begin{tabular}{|c|c|c|c|c|c|c|}
\hline \multirow{2}{*}{\multicolumn{3}{|c|}{ Chi-square test }} & \multicolumn{3}{|c|}{ Speed bump } & \multirow[b]{2}{*}{ Total } \\
\hline & & & Low & Sufficient & High & \\
\hline \multirow{8}{*}{ Speed limit } & \multirow{2}{*}{ High } & $\mathrm{N}$ & 1 & 9 & 1 & 11 \\
\hline & & $\%$ & 9.1 & 81.8 & 9.1 & 100.0 \\
\hline & \multirow[b]{2}{*}{ Low } & $\mathrm{N}$ & 10 & 126 & 224 & 360 \\
\hline & & $\%$ & 2.8 & 35.0 & 62.2 & 100.0 \\
\hline & \multirow{2}{*}{ Sufficient } & $\mathrm{N}$ & 19 & 161 & 112 & 292 \\
\hline & & $\%$ & 6.5 & 55.1 & 38.4 & 100.0 \\
\hline & \multirow{2}{*}{\multicolumn{2}{|c|}{ No opinion ${ }_{\%}^{N}$}} & 0 & 9 & 11 & 20 \\
\hline & & & 0.0 & 45.0 & 55.0 & 100.0 \\
\hline \multirow{2}{*}{ Total } & & $\mathrm{N}$ & 30 & 305 & 348 & 683 \\
\hline & & $\%$ & 4.4 & 44.7 & 51.0 & 100.0 \\
\hline \multicolumn{3}{|l|}{$\chi 2 / p$} & \multicolumn{4}{|c|}{$46.557 / 0.000$} \\
\hline \multirow{6}{*}{ Tendency to overtake vehicles } & \multirow{2}{*}{ Yes } & $\mathrm{N}$ & 3 & 40 & 79 & 122 \\
\hline & & $\%$ & 2.5 & 32.8 & 64.8 & 100.0 \\
\hline & \multirow{2}{*}{ No } & $\mathrm{N}$ & 19 & 150 & 141 & 310 \\
\hline & & $\%$ & 6.1 & 48.4 & 45.5 & 100.0 \\
\hline & \multirow{2}{*}{ Sometimes } & $\mathrm{N}$ & 10 & 136 & 148 & 294 \\
\hline & & $\%$ & 3.4 & 46.3 & 50.3 & 100.0 \\
\hline \multirow{2}{*}{ Total } & & $\mathrm{N}$ & 32 & 326 & 368 & 726 \\
\hline & & $\%$ & 4.4 & 44.9 & 50.7 & 100.0 \\
\hline \multicolumn{3}{|l|}{$\chi 2 / p$} & \multicolumn{4}{|c|}{$15.183 / 0.004$} \\
\hline
\end{tabular}




\section{DISCUSSION AND CONCLUSION}

Speed average for the D2 section with $50 \mathrm{~km} / \mathrm{h}$ speed limit was $49.31 \mathrm{~km} / \mathrm{h}$ which is below the speed limit, whereas the average for the speed average for the section without speed bumps was $52.99 \mathrm{~km} / \mathrm{h}$ which is above the speed limit. An increase of $3.68 \mathrm{~km} / \mathrm{h}$ was observed in the speed averages for the section without the speed bumps and a statistically significant difference has been observed between the averages of the average speeds for these drivers. There is a positive impact of the speed bumps in this section on average speed decrease. Whereas the average speeds of drivers who violate the speed limit with speed bumps on the section was $57.83 \mathrm{~km} / \mathrm{h}$, the speed value increased up to $62.54 \mathrm{~km} / \mathrm{h}$ when the speed bumps were removed. Standard deviation on the section without the speed bumps was 12.9734 and with the speed bumps it was 9.8241 . This indicates that speed variance among the vehicles on this section is lower with the speed bumps and hence it can be stated that there is an improved traffic flow as a result of the decrease of standard deviation for vehicle speed variance. According to these results, it has been observed that the speed bump used on the campus section has a positive impact on driver speeding behaviors. In addition, the speed limit enforced on this section is not neglected by majority of the drivers. It can be stated that this speed limit reflects the environmental context of the section and that it is in accordance with the expectations of the drivers.

According to the survey results in the study, $50 \%$ of the drivers indicated that the frequency of speed bumps in the campus is high, $45 \%$ stated that it is sufficient, whereas $4.4 \%$ indicated that it is low. If another system is put into effect in the campus by the administration as an alternative to speed bumps, contribution to driver satisfaction can be made by using a lower frequency of speed bumps. In addition, the chi-square analyses results have indicated that no statistically significant difference has been determined between the drivers who have and have not been involved in an accident with regard to their opinions on speed bump frequency.
Majority of the drivers who think that speed limits are high (62\%) and the drivers who think that their tendency to overtake other vehicles is high (\%64.8) are of the opinion that the number of speed bumps in the campus is high. It is observed that such drivers generally have positive opinions on speed enforcement systems.

\section{Acknowledgements}

This work is a part of the Project 2011010102007 'Application of the Mobile Automatic Plate Recognition System to the Akdeniz University Campus Against High Speed Problem and Evaluation of Effectiveness', which is financed by the Akdeniz University Scientific Research Projects Management Unit.

\section{REFERENCES}

[1]. Kaygısız Ö., Trafiği Sakinleştirmeye Yönelik Önlemler. Aydoğdu Ofset, EGM Trafik Araştırma Merkezi Müdürlüğü, Katalog No:696, Ankara, 2012.

[2]. Pau M., Angius S., Do speed bumps really decrease traffic speed? An Italian experience. Accident Analysis \& Prevention 33(5): 585-597, 2001.

[3]. WHO. Global status report on road safety 2015, Geneva, 2015.

[4]. Vet J.M., Thierry M.C., Horst A.R.A., Rahman A.K.M., The first integrated speed management program benefitting vulnerable road users in Bangladesh: results and implications for LMICs. In 17th International Conference Road Safety On Five Continents (RS5C 2016), Rio de Janeiro, Brazil, 17-19 May 2016 (pp. 1-21), 2016.

[5]. Cynecki M.J., Huang H.F., The Effects of Traffic Calming Measures on Pedestrian and Motorist Behavior. FHWA Report RD-00104, 2001

[6]. Patterson T., Local Area Traffic Management Schemes / Traffic Calming, Land Transport Safety Authority of New Zealand, Yeni Zelanda, 2004 
[7]. Taylor M.C., Lynam D.A., Baruya A., The Effects of Drivers' Speed on the Frequency of Road Accidents. TRL Report No:421, 2000.

[8]. Roberts C.A., Brown-Esplain J., Technical Evaluation of Photo Speed Enforcement for Freeways, Arizona, 2005.

[9]. Gil M.J.M., Malenstein U.P.M.J., Innovative Technology for Monitoring Traffic, Vehicles and Drivers, Police Enforcement Policy and Programmes on European Roads. 6th Framework Programme, European Commission, Technical Report, 2007.

[10]. Speed Check Service. Temporary Roadworks Speed Enforcement - M6, 2007. Address: http://www.speedcheck.co.uk/pdf/M6\%20T ASCAR\%20case\%20study.pdf

[11]. Speed Check Services, SPECS Safety Cameras-M4 10-12 Technology Upgrade, 2009. Address: http://www.speedcheck.co.uk/images/M4_ Case_Study.pdf

[12]. Speed Check Services, SPECS: Results, 2009.

Address:

http://www.speedcheck.co.uk/specs.htm

[13]. Young K.L., Regan M.A., Intelligent Transport Systems to Support Police Enforcement of Road Safety Laws. ATSB Research and Analysis Report No: 2007-02, 62p, 2007.

[14]. Cameron M., Development of Strategies for Best Practice in Speed Enforcement in Western Australia, Supplementary Report, Monash University Accident Research Centre, Melbourne, 2008.

[15]. Koy T, Benz S. Automatic Time-OverDistance Speed Checks İmpacts on Driving Behaviour and Traffic Safety. In the 6th ITS World Congress and Exhibition on Intelligent Transport Systems and Services, 2009.

[16]. Simcic G., Section Control: Towards a More Efficient and Better Accepted Enforcement of Speed Limits? Speed Fact Sheet 2, 2009.
[17]. Soole D., Fleiter J., Watson B., Point-toPoint Speed Enforcement. Report No: APR415-12., 2012.

[18]. Soole D.W., Watson B.C., Fleiter J.J., Effects of Average Speed Enforcement on Speed Compliance and Crashes: A review of the Literature,. Accident Analysis \& Prevention, 2013, 54: 46-56.

[19]. Montella A, Punzo V, Chiaradonna S, Mauriello F, Montanino M., Point-to-Point Speed Enforcement System: Speed Limits Design Criteria and Analysis of Drivers' Compliance. Transport. Res. Part C, 2015; 53: 1-18.

[20]. Speed Check Services, Temporary Roadworks Speed Enforcement - M1, 2006. Address: http://www.speedcheck.co.uk/pdf/M6\%20T ASCAR\%20case\%20study.pdf

[21]. Australian Transport Council, National Road Safety Strategy 2011-2020, Australian Transport Council, 2011.

[22]. Cameron M.H., Diamantopoulou K., Clark B., Langford J., Identifying Traffic Enforcement Practices and Opportunities in Western Australia, 2011.

Address: http://cmarc.curtin.edu.au/local/docs/ITEPOWA_ March2012.pdf

[23]. Lynch M., White M., Napier R., Investigation into the use of Point-to-Point Speed Cameras, NZ Transport Agency Research Report 465, 2011.

[24]. Soole D.W., Fleiter J.J., Watson B.C., Pointto-Point Speed Enforcement: Recommendations for Better Practice. Australasian Road Safety Research Policing and Education Conference, 28-30 August, 2013.

[25]. Høye A., Speed Cameras, Section Control, And Kangaroo Jumps - A Meta-Analysis. Accident Analysis \& Prevention, 2014; 73: 200-208.

[26]. Townsend E., Achterberg, F. Enforcement Monitor (No. 4). Brussels, Belguim: ETSC, 2005. 
[27]. Crawford E., Beyond 2010 - A Holistic Approach to Road Safety in Great Britain. Parliamentary Advisory Council for Transport Safety, London, 2009.
[28]. Korthof E.W., Effects of Section Control on Traffic Safety at Dutch Motorways. Delft University of Technology, Master Thesis, 202, Delft, 2014. 